\title{
Anti-Ro and anti-La autoantibodies induce TNF- $\alpha$ production by human salivary gland cells: an in vitro study
}

\author{
Gli autoanticorpi anti-Ro ed anti-La inducono la produzione di TNF- $\alpha$ \\ nelle cellule di ghiandole salivari umane: studio in vitro
}

\author{
M. Sisto ${ }^{1}$, S. Lisi ${ }^{1}$, M. D’Amore ${ }^{2}$, V. Mitolo ${ }^{1}$, P. Scagliusi ${ }^{2}$ \\ ${ }^{1}$ Dipartimento di Anatomia Umana ed Istologia; \\ ${ }^{2}$ Dipartimento di Medicina Interna e Medicina Pubblica, Sezione di Reumatologia, Università di Bari
}

\begin{abstract}
RIASSUNTO
Obiettivo: Lo scopo di questo studio è stato valutare la produzione di TNF- $\alpha$, induttore della via estrinseca del processo apoptotico, in seguito al trattamento con gli autoanticorpi anti-Ro ed anti-La isolati da pazienti con sindrome di Sjögren primaria in un modello sperimentale rappresentato dalla linea cellulare di ghiandole salivari umane, A253. Ė stata, inoltre, valutata la presenza sulla superficie di tali cellule di recettori specifici per tale induttore, TNFRI e TNFR2.

Materiali e metodi: Gli autoanticorpi anti-La ed anti-Ro sono stati purificati su una colonna cromatografia ad alta affinità. Le metodiche utilizzate per la valutazione della produzione di TNF- $\alpha$ e lo studio dei recettori di superficie sono state immunofluorescenza, RT-PCR e saggi immunoenzimatici.

Risultati: I nostri risultati hanno dimostrato che le cellule A-253 esprimono in superficie i recettori TNFR1 e TNFR2 e che gli autoanticorpi anti-Ro e anti-La sono in grado di indurre la produzione di TNF- $\alpha$ nelle stesse cellule.

Conclusioni: Il trattamento con gli autoanticorpi anti-Ro ed anti-La induce la produzione di TNF- $\alpha$ in cellule di ghiandole salivari umane e questo potrebbe spiegare la attivazione della via estrinseca della apoptosi.
\end{abstract}

Reumatismo, 2007; 59(3):221-226

\section{INTRODUCTION}

$\mathrm{T}_{\mathrm{p}}^{\mathrm{u}}$ umor necrosis factor alpha $(\mathrm{TNF}-\alpha)$ is a pleiotropic cytokine that plays a central role in inflammation (1) and apoptosis (2). It is synthesized as a $26 \mathrm{kDa}$, type II transmembrane protein that is 233 amino acids (aa) long (3). It contains a 30 aa cytoplasmic domain, a 26 aa transmembrane segment, and a 177 aa extracellular region (4). TNF- $\alpha$ is assembled intracellularly to form a transmembrane, non-covalently-linked homotrimeric

Indirizzo per la corrispondenza:

Prof. Pasquale Scagliusi

Dipartimento di Medicina Interna e Medicina Pubblica

Sezione di Reumatologia Policlinico

P.zza G. Cesare, 1 - 70124 Bari

E-mail: scagliusipasquale@libero.it protein. The 157 aa residue soluble form of TNF$\alpha$ is released from the $\mathrm{C}$-terminus of the transmembrane protein through the activity of the TNF$\alpha$-converting enzyme (TACE), a membrane-bound disintegrin metalloproteinase (5). TNF- $\alpha$ is mainly produced by activated macrophages and lymphocytes $(6,7)$, but human cells known to express TNF- $\alpha$ include epithelial cells (8), keratinocytes (9), plasma cells (10) and adipocytes (11). The role of TNF- $\alpha$ in host defence and inflammatory responses has been well documentated. It is a potent paracrine and endocrine mediator of inflammatory and immune function (12).

TNF- $\alpha$ is, moreover, a potent inducer of apoptosis; in fact, by binding to its receptors, TNF- $\alpha$ leads to the formation of death-inducing signalling complex (DISC), that activates caspase- 8 , the initiator protease of the extrinsic pathway of apopto- 
sis. In turn, caspase- 8 activates other downstream caspases, ultimately resulting in cell death (13, $14)$. The wide range of TNF- $\alpha$ activities is explained by the presence of TNF- $\alpha$ receptors (TNF$\alpha-R s$ ) on almost all nucleated cell types (15). In humans two distinct types of TNF- $\alpha$-Rs have been identified and molecularly cloned: TNF-R55 (also referred to as TNFR1, p55 or CD120a) and TNF-R75 (also called TNFR2, p75 or CD120b) with a molecular mass of $55 \mathrm{kDa}$ and $75 \mathrm{kDa}$, respectively $(16,17)$.

Because of the pleiotropic functions of TNF- $\alpha$ in immune and inflammatory processes, it is implicated as an important mediator in many diseases $(18,19)$ in which a dysregulation of the immune system or of apoptosis leads to pathogenesis. Much evidence supports the hypothesis that this happens also in autoimmune disease (20).

Sjögren's syndrome (SS) is an organ-specific autoimmune disorder characterized by the destruction of glandular structures.

Apoptosis of the acinar and ductal epithelial cells of the salivary and lachrymal glands has been proposed as a possible mechanism responsible for impairment of the secretory function. Apoptotic cell death may be induced either by cytotoxic $\mathrm{T}$ cells through the release of proteases (21) or by interaction of the Fas ligand, expressed by T lymphocytes, with Fas on epithelial cells (22). There is increasing evidence of the direct involvement of autoantibodies in tissue pathogenesis (23). The presence of serum autoantibodies directed against the ribonucleoprotein antigens SS-A (Ro) and SS-B (La) is one of the classification criteria used to identify Sjögren patients (24). Although there is a high correlation between the presence of serum autoantibodies and the development of SS, the exact role of these antibodies in the pathogenesis of the disease is still unclear.

Our previous work demonstrated that autoantibodies isolated from Sjögren IgG fractions are able, once they have penetrated inside the cells, to trigger the extrinsic pathway of apoptosis in the human salivary gland cell line A-253 (25).

To confirm the activation of the extrinsic apoptotic process pathway, in the present study, we investigate whether our experimental model, represented by the human salivary gland cell line, is able to produce TNF- $\alpha$ when stimulated with anti-Ro and anti-La autoantibodies. In addition, we investigate the presence of the TNF- $\alpha$-receptors, TNFR1 and TNFR2, on the surface of the salivary gland cells.

\section{MATERIALS AND METHODS}

\section{Cell cultures}

A-253 cells from human epidermoid carcinoma of the submaxillary gland (American Type Culture Collection, USA, number: HTB-41) were cultured in McCoy's 5a modified medium supplemented with $10 \%$ foetal bovine serum, $1 \%$ antibiotic solution, $2 \mathrm{mM} \mathrm{L}$-Glutamine, at $37^{\circ} \mathrm{C}, 5 \% \mathrm{CO}_{2}$ in air.

\section{Anti-Ro and anti-La autoantibodies purification}

Sera were collected from thirteen healthy volunteers and thirteen patients with primary Sjögren's syndrome, all fulfilling the American-European Consensus Group Classification criteria for SS (24). IgG was obtained from Sjögren and healthy sera by precipitation with ammonium sulphate at $50 \%(\mathrm{w} / \mathrm{v})$, and purified on protein $\mathrm{G}$ Sepharose (Amersham Pharmacia Biotech, Sweden). Anti-Ro and anti-La autoantibodies were purified from $S j o ̈-$ gren IgG fractions using Sepharose 4B-Ro and Sepharose 4B-La affinity columns (Amersham Pharmacia Biotech, Sweden) as recommended by the manufacturer. Anti-Ro and anti-La autoantibodies were used at a concentration of $20 \mu \mathrm{g} / \mathrm{ml}$ in all experimental procedures. Healthy $\mathrm{IgG}$, at the same concentration, were used as control for all experimental procedures.

\section{Determination of membrane receptors TNFR1 and TNFR2 in the A-253 cells}

Confocal microscopy and RT-PCR were used to determine whether the A-253 cell line shows the TNFR1 and TNFR2 receptors on the cell membrane. In the immunofluorescence assay, the A253 cells $\left(1 \times 10^{6}\right.$ cells/well $)$ were distributed in well microculture plates (Nunc, DK) after placement of a $175 \mu \mathrm{m}$-cellocate glass (Eppendorf, D). The cells were fixed with $2 \%(\mathrm{w} / \mathrm{v})$ paraformaldehyde (SIG$\mathrm{MA}$ ) in PBS for 10 min, and then treated with biotinylated anti-human TNFR1 and biotinylated anti-human TNFR2 (all antibodies were purchased from R\&D Systems, MN, USA) for $90 \mathrm{~min}$ at room temperature. Streptavidin (FITC) (Chemicon, CA, USA) was used for FITC secondary detection. The cells were observed using a confocal laser scanning microscopy system (Leica, TCS-SP2, Germany) using a $\lambda=488 \mathrm{~nm}$ Argon-Crypton laser for FITC. For RT-PCR analysis total cellular RNA was extracted from A-253 cells using the RNAzol bee isolation reagent (Tel-Test, TX, USA) according to the manufacturer's instructions. First-strand cDNA was synthesized from $1 \mu \mathrm{g}$ total cell RNA using the 
Superscript II reverse transcriptase kit (Life Technologies, UK). The following primer pairs were used for amplification: TNFR1, forward 5'-ACCAAGTGCCACAACGGAAC-3' and reverse 5'CTGCAATTGAAGCACTGGAA-3'; TNFR2, forward 5'-CTCAGGAGCATGGGGATAAA-3' and reverse 5'-AGCCAGCCAGTCTGACATCT-3'. GADPH was used as control and the primers used to amplify it were: GADPH forward 5'-CAACGGATTTGGTCGTATT-3' and GADPH reverse 5'GATGGCAACAATATCCACTT-3' primer pairs. The PCR products of the expected size were visualized with ethidium bromide in $1.2 \%(\mathrm{w} / \mathrm{v})$ agarose gel electrophoresis and confirmed by sequencing.

\section{A-253 cells treatment}

Cell cultures were subjected to the following treatments: 1) anti-Ro autoantibodies $(20 \mu \mathrm{g} / \mathrm{ml})$ from Sjögren IgG for 16h; 2) anti-Ro autoantibodies (20 $\mu \mathrm{g} / \mathrm{ml}$ ) from Sjögren IgG for 24h; 3) anti-La autoantibodies $(20 \mu \mathrm{g} / \mathrm{ml})$ from Sjögren IgG for $16 \mathrm{~h}$; 4) anti-La autoantibodies $(20 \mu \mathrm{g} / \mathrm{ml})$ from Sjögren $\mathrm{IgG}$ for $24 \mathrm{~h}$. Untreated cells and cells treated with healthy $\operatorname{IgG}(20 \mu \mathrm{g} / \mathrm{ml})$ for $16 \mathrm{~h}$ and $24 \mathrm{~h}$ were used as control.

\section{TNF- $\alpha$ production analysis}

We employed an ELISA assay and RT-PCR to visualize TNF- $\alpha$ production by the A-253 cells. For the ELISA test the Quantikine human TNF- $\alpha$ immunoassay was used (R\&D Systems, MN, USA). For RT-PCR the following primer pairs were used for amplification: TNF- $\alpha$ forward 5'-TCCTTCAGACACCCTCAACC-3' and reverse 5'-AGGCCCCAGTTTGAATTCTT-3'; the PCR products of the expected size were visualized with ethidium bromide in $1.2 \%(\mathrm{w} / \mathrm{v})$ agarose gel electophoresis and confirmed by sequencing. The results are expressed as the mean $\pm \mathrm{SE}$ of six experiments performed in duplicate.

\section{Densitometric analysis}

The bands obtained after RT-PCR for TNF- $\alpha$ production were submitted to densitometric analysis using 1D Image Analyses Software (Kodak Digital Science, Rochester, NY). The results are expressed as arbitrary units.

\section{Statistical analysis}

The data were analyzed for normality using the Wilks Shapiro Test. Differences in means for paired observations were analysed by Student's t-test. In

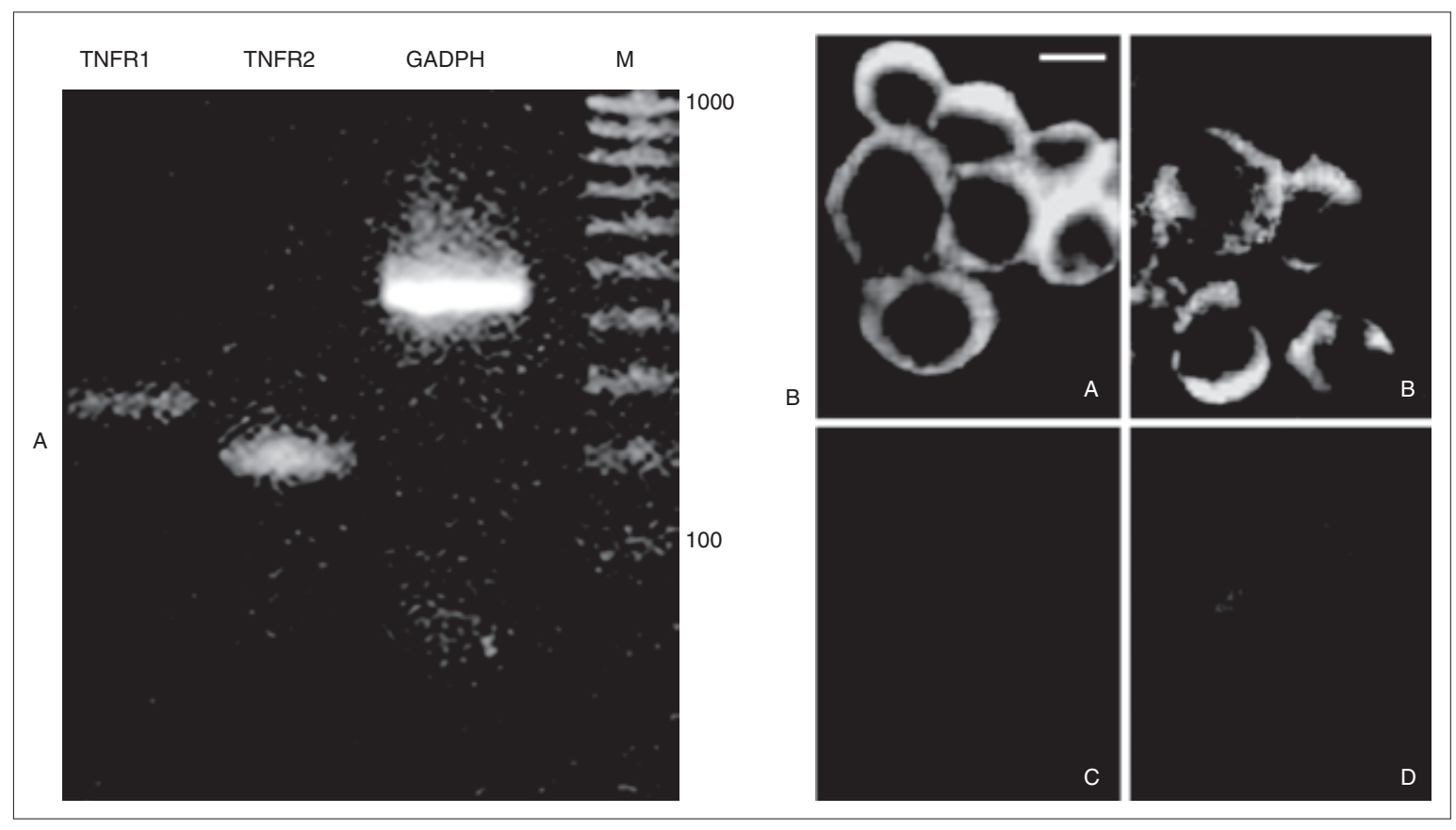

Figure 1 - Expression of the TNFR1 e TNFR2 receptors by the salivary gland cells. For RT-PCR analysis products of the expected size were visualized through agarose gel electrophoresis. M, marker. RT PCR of GADPH was used as control (panel A). For confocal microscopy, cells were treated with biotinylated anti-human TNFR1 and biotinylated anti-human TNFR2. Streptavidin (FITC) was used for FITC secondary detection. Expression of TNFR1 (A), TNFR2 (B), untreated control cells (C), cells treated with streptavidin (FITC) (D). Scale bar = $10 \mu \mathrm{m}$. 
all instances values of $p<0.05$ were considered statistically significant.

\section{RESULTS}

\section{Evidence for TNFR1 and TNFR2 expression in} A-253 cells

Confocal microscopy and RT-PCR were employed to demonstrate that A-253 cells express the TNFR1 and the TNFR 2 receptors. Figure 1 shows the mRNA expression for TNFR1 and TNFR2 by the A253 cells (panel A). These results were confirmed by an immunofluorescence assay (Fig. 1, panel B) that evidences the expression of TNFR1 and TNFR2 on the A-253 cell membrane (A=TNFR1; $\mathrm{B}=\mathrm{TNFR} 2$ ). No fluorescence was detected in cells treated with paraformaldehyde or with streptavidin (FITC) only (C, D).

\section{TNF- $\alpha$ induction by anti-Ro and anti-La auto- antibodies treatment}

Cell treatment with the anti-Ro autoantibodies from Sjögren IgG determines TNF- $\alpha$ production, that reached a maximum at 16 hours. When the ELISA test was repeated at 24 and 48 hours the TNF- $\alpha$ production was significantly reduced $(\mathrm{p}<0.05)$ (Fig. 2, panel A). These results were confirmed by RT-

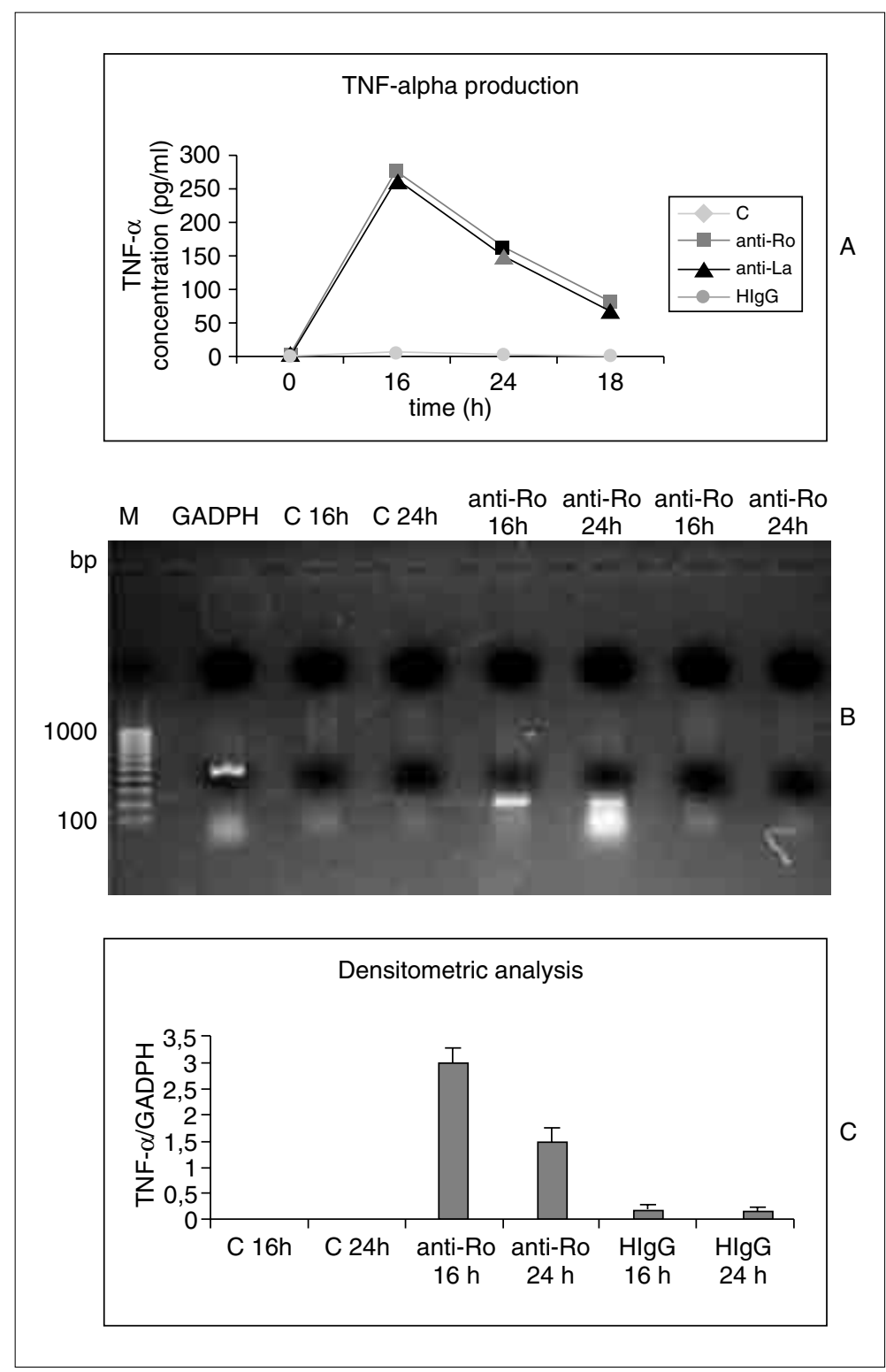

Figure 2 - Assays for TNF- $\alpha$ production. For the ELISA assay (panel A), the A-253 cells were treated with anti-Ro ( $\square$ ), anti-La $(\mathbf{\Delta})$ and healthy $\operatorname{lgG}(\bullet)$ Untreated control cells are indicated with $\diamond$. The results are representative of six experiments (mean $\pm \mathrm{SE}$ ). In the RT-PCR analysis (panel B), products of the expected size were visualized through agarose gel electrophoresis. $M$, marker; C, untreated control cells; anti-Ro 16h, A-253 cells treated with anti-Ro for 16 hours; anti-Ro 24h, A-253 cells treated with anti-Ro autoantibodies for 24 hours; $\mathrm{H}$ IgG 16h, A-253 cells treated with healthy $\lg \mathrm{G}$ for 16 hours; $\mathrm{H} \operatorname{lgG} 24 \mathrm{~h}$, A-253 cells treated with healthy $\lg \mathrm{G}$ for 24 hours. RT PCR of GADPH was used as control. Panel C shows the semiquantitative RT-PCR analysis of TNF- $\alpha$ production. Densitometric analysis was performed after normalization against GADPH. 
PCR (Fig. 2, panel B). Treatment with the anti-La autoantibodies yielded the same results (data not shown). Cells treatment with healthy IgG induces comparable TNF- $\alpha$ levels to untreated control cells.

\section{Densitometric analysis}

There is an increase in TNF- $\alpha$ mRNA expression in cells treated with anti-Ro for $16 \mathrm{~h}$ compared to untreated control cells and cells treated with healthy IgG. After $24 \mathrm{~h}$ from anti-Ro treatment, a decrease of the TNF- $\alpha$ mRNA levels is observed (Fig. 2, panel C). Anti-La autoantibodies cells treatment yielded the same results (data not shown).

\section{DISCUSSION}

Several findings suggest that there is a relationship between the binding and penetration of autoantibodies in the different cell types and the triggering of events leading to various functional cellular alterations (26). One of the most interesting effects of autoantibody penetration is the induction of programmed cell death (27). Growing evidence suggests that deregulation of apoptosis is involved in autoimmunity (28), and recently, research ad- vances have supported the idea that, once they have penetrated cells, autoantibodies can be directly pathogenic and directly trigger the apoptotic pathway (29). There is now evidence, in Sjögren's syndrome, of a correlation between autoantibody penetration of salivary epithelial cells and a direct role in causing apoptotis. Sisto et al. (25) demonstrated that, in an experimental model of the human salivary gland cell line A-253, autoantibodies contained in IgG purified from Sjögren sera are able, once they have penetrated inside cells, to trigger cell death through apoptotic mechanisms, in a caspase-dependent manner, in which both the extrinsic and intrinsic pathways play a role.

In this study we clarify which could be the inducer of the extrinsic pathway of apoptosis, investigating TNF- $\alpha$ production following anti-Ro and anti-La autoantibodies treatment of the cells. Results obtained demonstrate that the salivary gland cells show TNF receptors on their cellular surface, and that anti-Ro and anti-La autoantibodies significantly enhance the release of TNF- $\alpha$, in comparison with cells treated with healthy $\operatorname{IgG}$ and untreated control cells. However, much still remains unknown about the signal transduction pathway regulated by TNF- $\alpha$.

\section{SUMMARY}

In this report, we demonstrate that both TNFR1 and the TNFR2 are expressed on the salivary gland cell line A-253 cell membrane. Furthermore, cell treatment with anti-Ro and anti-La autoantibodies from Sjögren IgG determined TNF- $\alpha$ production, clarifying which could be the inducer of the extrinsic pathway of apoptosis in salivary gland cells.

Parole chiave - Fattore di necrosi tumorale alpha, autoanticorpi, sindrome di Siögren.

Key words - Tumor necrosis factor alpha, autoantibodies, Siögren's syndrome.

\section{REFERENCES}

1. Kelker HC, Oppenheim JD, Stone-Wolff D, Henriksen-destefano D, Aggarwal BB, Stevenson HC, et al. Characterization of human tumor necrosis factor produced by peripheral blood monocytes and its separation from lymphotoxin. Int J Cancer 1985; 36: 69.

2. Sedgwick JD, Riminton DS, Cyster JG, Korner H. Tumor necrosis factor: a master-regulator of leukocyte movement. Immunol Today 2000; 21: 110-3.

3. Pennica D, Nedwin GE, Hayflick JS, Seeburg PH, Derynck R, Palladino MA, et al. Human tumour necrosis factor: precursor structure, expression and homology to lymphotoxin. Nature 1985; 2, 312: 724-9.

4. Wang AM, Creasey AA, Ladner MB, Lin LS, Strick- ler J, Van Arsdell JN, et al. Molecular cloning of the complementary DNA for human tumor necrosis factor. Science 1985; 228: 149-54.

5. Schlondorff J, Becherer JD, Blobel CP. Intracellular maturation and localization of the tumour necrosis factor alpha convertase (TACE). Biochem J 2000; 1, 347: 131-8.

6. Kelker HC, Oppenheim JD, Stone-Wolff D, Henriksen-DeStefano D, Aggarwal BB, Stevenson HC, et al. Characterization of human tumor necrosis factor produced by peripheral blood monocytes and its separation from lymphotoxin. Int J Cancer 1985; 36: 69-73.

7. Cuturi MC, Murphy M, Costa-Giomi MP, Weinmann R, Perussia B, Trinchieri G. Independent regulation of tumor necrosis factor and lymphotoxin production by 
human peripheral blood lymphocytes. J Exp Med 1987; 165: 1581-94.

8. Jung HC, Eckmann L, Yang SK, Panja A, Fierer J, Morzycka-Wroblewska E, et al. A distinct array of proinflammatory cytokines is expressed in human colon epithelial cells in response to bacterial invasion. J Clin Invest 1995; 95: 55-65.

9. Ezepchuk YV, Leung DY, Middleton MH, Bina P, Reiser R, Norris DA. Staphylococcal toxins and protein A differentially induce cytotoxicity and release of tumor necrosis factor-alpha from human keratinocytes. J Invest Dermatol 1996; 107: 603-9.

10. Di Girolamo N, Visvanathan K, Lloyd A, Wakefield D. Expression of TNF-alpha by human plasma cells in chronic inflammation. J Leukoc Biol 1997; 61: 667-78.

11. Hotamisligil GS, Arner P, Caro JF, Atkinson RL, Spiegelman BM. Increased adipose tissue expression of tumor necrosis factor-alpha in human obesity and insulin resistance.J Clin Invest 1995; 95: 2409-15.

12. Connell L, McInnes IB. New cytokine targets in inflammatory rheumatic diseases.Best Pract Res Clin Rheumatol 2006; 20: 865-78.

13. Cauwels A, Brouckaert P. Survival of TNF toxicity: Dependence on caspases and NO. Arch Biochem Biophys 2007; 462: 132-9.

14. Chaudhari BR, Murphy RF, Agrawal DK. Following the TRAIL to apoptosis. Immunol Res 2006; 35: 24962.

15. Arch RH. Function of tumor necrosis factor receptor family members on regulatory T-cells. Immunol Res 2005; 32: 15-29.

16. Smith RA, Kirstein M, Fiers W, Baglioni C. Species specificity of human and murine tumor necrosis factor. A comparative study of tumor necrosis factor receptors. J Biol Chem 1986; 261: 14871-4.

17. Declercq W, Vandenabeele P, Fiers W. Dimerization of chimeric erythropoietin/75 kDa tumour necrosis factor (TNF) receptors transduces TNF signals: necessity for the $75 \mathrm{kDa}-\mathrm{TNF}$ receptor transmembrane domain. Cytokine $1995 ; 7$ : 701-9.

18. Naoum JJ, Chai H, Lin PH, Lumsden AB, Yao Q, Chen C. Free Full Text Lymphotoxin-alpha and cardiovas- cular disease: clinical association and pathogenic mechanisms. Med Sci Monit 2006; 12: RA121-4.

19. Ghezzi P, Cerami A. Tumor necrosis factor as a pharmacological target. Mol Biotechnol 2005; 31: 239-44.

20. Baugh JA, Bucala R. Mechanisms for modulating TNF alpha in immune and inflammatory disease. Curr Opin Drug Discov Devel 2001; 4: 635-50.

21. Cohen GM. Caspases: the executioners of apoptosis. Biochem J 1997; 15: 1-16.

22. Saikumar P, Dong Z, Mikhailov V, Denton M, Weinberg JM, Venkatachalam MA. Apoptosis: definition, mechanisms, and relevance to disease. Am J Med. 1999; 107: 489-506.

23. Delaleu N, Jonsson MV, Jonsson R. Disease mechanism of Sjögren's syndrome. Drug discovery today: Dis Mech 2004; 3: 329-36.

24. Vitali C, Bombardieri S, Moutsopoulos HM, Balestrieri G, Bencivelli W, Bernstein RM, et al. Preliminary criteria for the classification of Sjögren's syndrome. Results of a prospective concerted action supported by the European Community. Arthritis Rheum 1993; 36: 340-7.

25. Sisto M, Lisi S, Castellana D, Scagliusi P, D'Amore M, Caprio S, et al. Autoantibodies from Sjogren's syndrome induce activation of both the intrinsic and extrinsic apoptotic pathways in human salivary gland cell line A-253. J Autoimmun 2006; 27: 38-49.

26. Alarcón-Segovia D, Llorente L, Ruiz-Arguelles A, Richaud-Patin Y, Pérez Romano B. Penetration of anti-DNA antibodies into mononuclear cells causes apoptosis. Arthritis Rheum 1995; 38: S179.

27. Ma J, Chapman GV, Chen SL, Melick G, Penny R, Breit SN. Antibody penetration of viable human cells. I. Increased penetration of human lymphocytes by anti-RNP IgG. Clin Exp Immunol 1991; 84: 83-91.

28. Ruiz-Arguelles A, Perez-romano B, Llorente L, Alarcon-Segovia D, Castellanos JM. Penetration of antiDNA antibodies into immature live cells. J Autoimmun 1998; 11: 547-56.

29. Shiraga S, Adamus G. Mechanism of CAR syndrome: anti-recoverin antibodies are the inducers of retinal cell apoptotic death via the caspase 9- and caspase 3-dependent pathway. J Neuroimmunol 2002; 132: 72-82. 